\title{
The appointment of executive heads in UN treaty-based organizations
}

\author{
Francis W. Hoole
}

\begin{abstract}
The research reported in this article seeks to understand how and why individuals are appointed to serve as executive heads of international organizations. A simple statement of the behavioral rule used in selection of executive heads is developed in the form of an executive head appointment function. The type of data available for the analysis of the appointment of executive heads in international organizations is identified, and an empirical examination of changes in emphasis in the selection of executive heads is reported. The executive head appointment function utilized in the study views appointment as an executive head as a function of six factors (three organizational, one national, and two personal). Discriminant function analysis is used to determine if the function would distinguish between individuals appointed during the period 1945-57 and those appointed from 1958-70 as executive heads in UN treaty-based organizations. It is possible to distinguish, on the basis of the specified executive head appointment function, between executive heads appointed during the two halves of the time period under study. It is therefore reasonable to conclude that the emphasis involved in the selection of executive heads has changed over time in UN treaty-based organizations.
\end{abstract}

Francis W. Hoole is a member of the Department of Political Science at Indiana University. This study was supported by United States Government National Science Foundation Grant GS39996, A Computerized International Organization Data Archive, 1973-74, and by Ford Foundation funds granted Indiana University to encourage international studies. I am grateful to the Carnegie Endowment for International Peace and the Centre de Recherches sur les Institutions Internationales for facilitating the final writeup by providing office space and secretarial assistance in Geneva, Switzerland. I would like to thank Ronald Weber and Harvey Tucker for valuable statistical aid and the editor and anonymous reviewers of this journal for helpful editorial advice. I am responsible for any errors contained in the article. 


\section{Introduction}

Studying policy makers has been one of the favorite pastimes of international organization scholars. For example, considerable attention has been devoted to various aspects of the international civil service, election of individuals to international parliamentary leadership positions, the political role of specific secretariesgeneral of international governmental organizations (IGOs), the overall impact of executive heads in shaping activities undertaken by international organizations, behavior of governmental representatives in public meetings, and attitude formation by delegates to international conferences. Unfortunately, no systematic comparative study has previously been reported which focuses on the appointment of executive heads in international organizations. ${ }^{1}$ The research reported in this article was undertaken to correct that oversight and has as its concern the understanding of how and why individuals are appointed to serve as executive heads of international organizations.

There are a variety of legitimate research approaches which could be utilized in this study. The historical approach emphasizes the reconstruction of particular events. The legalistic approach focuses on constitutional provisions, laws, treaties, regulations and legal bases for action. The ideological approach orients analysis around sets of beliefs. The behavioral approach emphasizes behavior, assignment of numerical values to empirical evidence, and statistical analysis. Other approaches, naturally, emphasize other factors. Because of availability of data and the personal preference of the author the work reported here falls within the behavioral tradition. The article exhibits the general advantages and limitations contained in that approach.

The research is purposely exploratory in nature. A simple statement of the behavioral rule used in the selection of executive heads is developed in the form of an executive head appointment function, the type of data available for the analysis of the appointment of executive heads in international organizations is identified, and an empirical examination of changes in emphasis in the selection of executive heads is reported. While the agencies studied, UN treaty-based organizations, and the years examined, 1945-70, may present biases in regard to the population to which generalizations eventually should be addressed, the study, nevertheless, examines data that is probably not too atypical. Hopefully the article provides a foundation for additional study. It begins with a presentation of the theoretical orientation utilized in the research, moves to operational considerations and then reports on the empirical examination of changes in emphasis in the executive head selection process. It ends with a statement of the study's conclusion and suggestions for further research.

\footnotetext{
${ }^{1}$ The background characteristics of certain secretaries-general of international nongovernmental organizations have been collected by Lawrence Young and Kjell Skjelsbaek. See Lawrence J. Young, "Secretaries General in International Non Governmental Organizations (INGOs)," International Associations 1971/7 (August-September 1971): 396-403; and Kjell Skjelsbaek, "A Survey of International Nongovernmental Organizations-2," International Associations 1974/6-7 (June-July 1974): 352-4.
} 


\section{Theoretical orientation}

The appointment of an individual to serve as executive head is one of the most important actions taken by an international organization and is usefully viewed from a policy-making perspective. ${ }^{2}$ A policy is a course or line of action. An action is a deed or behavior, such as the appointment of an executive head. A decision is a choice among alternative actions. A policy-making process consists of the series of activities involved in making and executing decisions. In IGOs this is a political process where a number of policy makers become involved in a struggle over a variety of organizational actions. This process is highly structured and complex, and can be viewed as a system. Inputs into the system consist of information which comes into the policy-making process. Outputs are the system's products, called actions. The system is the mechanism, called a policy-making process, which transforms inputs into outputs. Feedback consists of information regarding results of actions, and is fed back into the system as a subsequent input.

It is, of course, the participants in the policy-making process who bargain and negotiate over proposed actions, evaluating inputs into the system and deciding on actions for the organization. In engaging in this activity they develop patterns of behavior which can be stated as policy-making rules. A policy-making rule is the calculus by which information coming into a policy-making process is transformed into organizational action. Such a rule expresses outputs as specific functions of particular input variables and can be viewed as a formal statement of the behavior of policy makers on a specific issue.

When deciding on the appointment of an individual to an executive head position in an international organization the policy makers take into account a variety of personal, national, and organizational factors. Thus $Z=f\left(X_{1}, X_{2}, X_{3}\right)$, where $Z$ is appointment as executive head, $X_{1}$ is a vector of personal characteristics, $X_{2}$ is a vector of characteristics of the appointee's native country, and $X_{3}$ is a vector of organizational characteristics. When the exact variables and the mathematical form of the function have been fully specified this statement will be regarded as the executive head appointment function and viewed as the behavioral policy-making rule used for the appointment of executive heads in international organizations.

The focus of this article will be on a systematic examination of whether the emphasis on personal, national and organizational factors in the selection of executive heads has changed over time in UN treaty-based organizations. ${ }^{3}$ This will be

\footnotetext{
${ }^{2}$ For an elaboration of the policy-making perspective presented here see Francis W. Hoole, 'olitics and Budgeting in the World Health Organization (Bloomington, Ind.: Indiana University 'ress, forthcoming).

${ }^{3}$ The acid test of such a function would be the evaluation of its ability to make accurate redictions about future appointments. Furthermore, a strong empirical test would include ome individuals who were appointed and some who were not. This type of test would create in interesting variation in the dependent variable and would set up an evaluation of the unction's ability to predict or postdict appointments and non-appointments. Unfortunately lata for those tests are currently not available to me. To date I have been able to obtain only
} 
done by asking whether it is possible to distinguish, on the basis of a fully specified executive head appointment function, between executive heads appointed during the first half of the period under study and those appointed later. Because an important part of the specification of the function involves reducing the ambiguity contained in general terms like "personal," "national," and "organizational" by identifying specific personal, national, and organizational variables, and because the assignment of a value for each variable to each individual is important, let us turn to a consideration of the operational aspects of the study.

\section{Operational considerations}

During the twenty-six year period being studied a total of forty-seven individuals from nineteen different countries assumed the position of executive head of one of the agencies in the sample. The names of these individuals, together with their country, organization, term of office, age upon assuming office, and prior experience in their agency's secretariat are presented in table $1 .^{4}$ A quick glance at the list of names indicates that many of the well-known leaders in the history of the United Nations system are included. Founding fathers like Trygve Lie and Brock Chisholm are there, along with other famous executive heads like David A. Morse, Dag Hammarskjold, U Thant and Robert S. McNamara. The data reveal that the appointees averaged fifty-five years of age when assuming office, served for an average of six years, and eleven of the forty-seven appointees had prior service in

\footnotetext{
data on the individuals actually appointed. Thus the examination of whether the details (either the values of the variables or the weights given to the variables) concerning the factors contained in the function have changed is all that is proper at this time.

${ }^{4}$ The data reported in table 1 were collected from the following sources: Yearbook of the United Nations (New York: United Nations, 1947-70); The International Who's Who, ThirtySeventh Edition, 1973-74 (London: Europa Publications Ltd., 1973); The International Who's Who, Thirtieth Edition, 1966-67 (London: Europa Publications Ltd., 1966); The International Who's Who, Twenty-Seventh Edition, 1963-64 (London: Europa Publications Ltd., 1963); The International Who's Who, Nineteenth Edition, 1955 (London: Europa Publications Ltd., 1955); The International Who's Who, Eleventh Edition, 1947 (London: George Allen and Unwin, 1947); Who Was Who, 1961-1970 (London: Adam and Charles Black, 1972); Who Was Who, 1951-1960 (London: Adam and Charles Black, 1961); World Biography, Fifth Edition (Bethpage, New York: Institute for Research in Biography, Inc., 1954); Who's Who in the World, lst Edition, 1971-1972 (Chicago: Marquis Who's Who, Inc., 1970); Who's Who in the United Nations (Yonkers-on-Hudson, New York: Christian E. Burckel and Associates, 1951); The Canadian Who's Who, Volume XII, 1970-1972 (Toronto: Who's Who Canadian Publications, 1972); and The New York Times, June 19, 1958, November 22, 1961 and February 20, 1967, A second person collected a randomly selected duplicate set of twenty percent of these data. There were no intercoder differences. This was probably because the data were copied in a straightforward manner and little coding was involved. The same procedure was used for the data in table 3 and the same results were obtained, probably for the same reason. It is a weakness of the study that intuition and availability of data, rather than prior explicit theoretical statements, guided the selection of the data.
} 
Table 1. Executive heads appointed 1945-70

\begin{tabular}{|c|c|c|c|c|c|}
\hline Name & Country & Organization & Term & $\begin{array}{l}\text { Age upon } \\
\text { assuming } \\
\text { office }\end{array}$ & $\begin{array}{l}\text { Prior expe- } \\
\text { rience in } \\
\text { secretariat }\end{array}$ \\
\hline John Boyd Orr & United Kingdom & $\mathrm{FAO}$ & $1945-48$ & 65 & 0 \\
\hline Trygve Lie & Norway & UN & $1946-53$ & 50 & 0 \\
\hline Julian Huxley & United Kingdom & UNESCO & $1946-48$ & 59 & 0 \\
\hline Eugene Meyer & United States & IBRD & $1946-47$ & 71 & 0 \\
\hline Camile Gutt & Belgium & IMF & $1946-51$ & 62 & 0 \\
\hline Albert Roper & France & $\mathrm{ICAO}$ & $1947-51$ & 56 & 0 \\
\hline John J. McCloy & United States & IBRD & $1947-49$ & 52 & 0 \\
\hline David A. Morse & United States & ILO & $1948-70$ & 41 & 0 \\
\hline Norris E. Dodd & United States & FAO & $1948-54$ & 69 & 0 \\
\hline Jaime Torres Bodet & Mexico & UNESCO & $1948-52$ & 46 & 0 \\
\hline Brock Chisholm & Canada & WHO & $1948-53$ & 52 & 0 \\
\hline \multirow[t]{3}{*}{ Eugene R. Black } & United States & IBRD & $1949-62$ & 51 & 0 \\
\hline & & IDA & $1960-62$ & & \\
\hline & & IFC & $1961-62$ & & \\
\hline Fritz Hess & Switzerland & UPU & $1950-61$ & 55 & 0 \\
\hline Leon Mulatier & France & $\operatorname{ITU}$ & $1950-53$ & 63 & 10 \\
\hline Ivar Rooth & Sweden & IMF & $1951-56$ & 63 & 0 \\
\hline Gustav Swoboda & Switzerland & WMO & $1951-55$ & 58 & 0 \\
\hline E.C.R. Ljungberg & Sweden & ICAO & $1952-59$ & 55 & 0 \\
\hline Dag Hammarskjold & Sweden & UN & $1953-61$ & 48 & 0 \\
\hline Luther H. Evans & United States & UNESCO & $1953-58$ & 51 & 0 \\
\hline Marcolino Candau & Brazil & WHO & $1953-$ & 42 & 3 \\
\hline Philip V. Cardon & United States & FAO & $1954-56$ & 65 & 0 \\
\hline Marco A. Andrada & Argentina & ITU & $1954-58$ & 50 & 0 \\
\hline David A. Davies & United Kingdom & WMO & $1955-$ & 42 & 0 \\
\hline Binay R. Sen & India & $\mathrm{FAO}$ & $1956-67$ & 58 & 0 \\
\hline Per Jacobsson & Sweden & IMF & $1956-63$ & 62 & 0 \\
\hline Robert L. Garner & United States & IFC & $1956-67$ & 62 & 0 \\
\hline W. Sterling Cole & United States & IAEA & $1957-61$ & 53 & 0 \\
\hline Vittorino Veronese & Italy & UNESCO & $1958-61$ & 48 & 0 \\
\hline Gerald C. Gross & United States & ITU & $1958-65$ & 55 & 13 \\
\hline R.M. Macdonnell & Canada & ICAO & $1959-64$ & 50 & 0 \\
\hline Ove Nielsen & Denmark & IMCO & $1959-61$ & 66 & 0 \\
\hline U Thant & Burma & UN & $1961-$ & 52 & 0 \\
\hline Rene Maheu & France & UNESCO & $1961-$ & 56 & 15 \\
\hline Edouard Weber & Switzerland & UPU & $1961-66$ & 50 & 0 \\
\hline Sigvard A. Eklund & Sweden & IAEA & $1961-$ & 50 & 0 \\
\hline \multirow[t]{3}{*}{ George D. Woods } & United States & IBRD & $1963-68$ & 62 & 0 \\
\hline & & IDA & $1963-68$ & & \\
\hline & & IFC & $1963-68$ & & \\
\hline Pierre-Paul Schweitzer & France & IMF & $1963-$ & 51 & 0 \\
\hline Jean Roullier & France & IMCO & $1963-68$ & 65 & 0 \\
\hline Bernard T. Twigt & Netherlands & ICAO & $1964-70$ & 52 & 7 \\
\hline Manohar B. Sarwate & India & ITU & $1966-67$ & 55 & 7 \\
\hline Michel Rahi & Egypt & UPU & $1967-$ & 55 & 17 \\
\hline Mohamed Mili & Tunisia & ITU & $1967-$ & 50 & 7 \\
\hline Addeke H. Boerma & Netherlands & FAO & $1968-$ & 56 & 20 \\
\hline \multirow[t]{3}{*}{ Robert S. McNamara } & United States & IBRD & $1968-$ & 52 & 0 \\
\hline & & IDA & $1968-$ & & \\
\hline & & IFC & $1968-$ & & \\
\hline Colin Goad & United Kingdom & IMCO & $1968-$ & 54 & 5 \\
\hline Wifred Jenks & United Kingdom & ILO & $1970-$ & 61 & 39 \\
\hline Assad Kotaite & Lebanon & ICAO & $1970-$ & 56 & 0 \\
\hline
\end{tabular}


the secretariat of the agency which they were appointed to head. The information in the table indicates the type of personal data available for the study of the appointment of executive heads in international organizations. Using standard biographical sources no other intuitively interesting personal data could be compiled for all appointees. The individuals in the sample were used in the empirical examination reported in this article, with the variables age upon assuming office and prior experience in secretariat serving as indicators of the personal characteristics of the appointees.

A majority of the appointees have come from a handful of countries, with individuals from the United States comprising twenty-six percent of the appointees and persons from France, Sweden, the United Kingdom and the United States making up fifty-seven percent of the sample. Furthermore, thirty-eight of the forty-seven individuals ( 81 percent) appointed between 1945 and 1970 came from countries located in North America or Western Europe. The data complement the earlier findings of Singer and Sensenig, Gregg, and Weigert and Riggs that UN officeholding (defined by them as elected offices in the UN General Assembly and its main committees, and seats in other major UN organs which are filled by the Assembly) is related to the capabilities, or development, of the individual's native country. ${ }^{5}$ It was decided to use the percent of budget assessment for 1966 as the indicator of the characteristics of the native country of the appointee in the empirical examination reported in this article. ${ }^{6}$ These data are presented in table 2 along with a recoding of the data from table 1 .

In 1966 there were nineteen-hundred and thirty-five international nongovernmental organizations and one-hundred and ninety-nine international governmental organizations. One-hundred and seventy-four of the international governmental organizations existed outside of the United Nations system while the other twentyfive organizations were universal membership agencies inside the UN family. ${ }^{7}$ Within the United Nations system there were fourteen semi-autonomous organiza-

\footnotetext{
${ }^{5}$ Marshall R. Singer and Barton Sensenig III, "Elections within the United Nations: An Experimental Study Utilizing Statistical Analysis," International Organization 17 (Autumn 1963): 901-25; Robert W. Gregg, "The Latin American Bloc in United Nations Elections," Southwestern Social Science Quarterly 46 (September 1965): 146-54; and Kathleen Maas Weigert and Robert E. Riggs, "Africa and United Nations Elections: An Aggregate Data Analysis," International Organization 23 (Winter 1969): 1-19.

${ }^{6}$ The scale of assessments from the World Health Organization (WHO) was used because it includes all nations listed in table 2 whereas the United Nations (UN) scale of assessments does not. Actually WHO takes the UN scale from the prior year and adjusts it for membership differences. The budget assessments listed in table 2 were taken from Official Records of the World Health Organization, No. 159, Financial Report, 1 January-31 December 1966 (Geneva: World Health Organization, 1967): 17-9. Gross National Product, Gross Domestic Product or some other indicator could have been used. Since most indicators of development or wealth are highly correlated it probably does not make too much difference which is used for preliminary analysis. In future analyses multiple indicators should be utilized.

${ }^{7}$ Yearbook of International Organizations, 12th (1968-69) Edition (Brussels: Union of International Associations, 1969): 13.
} 


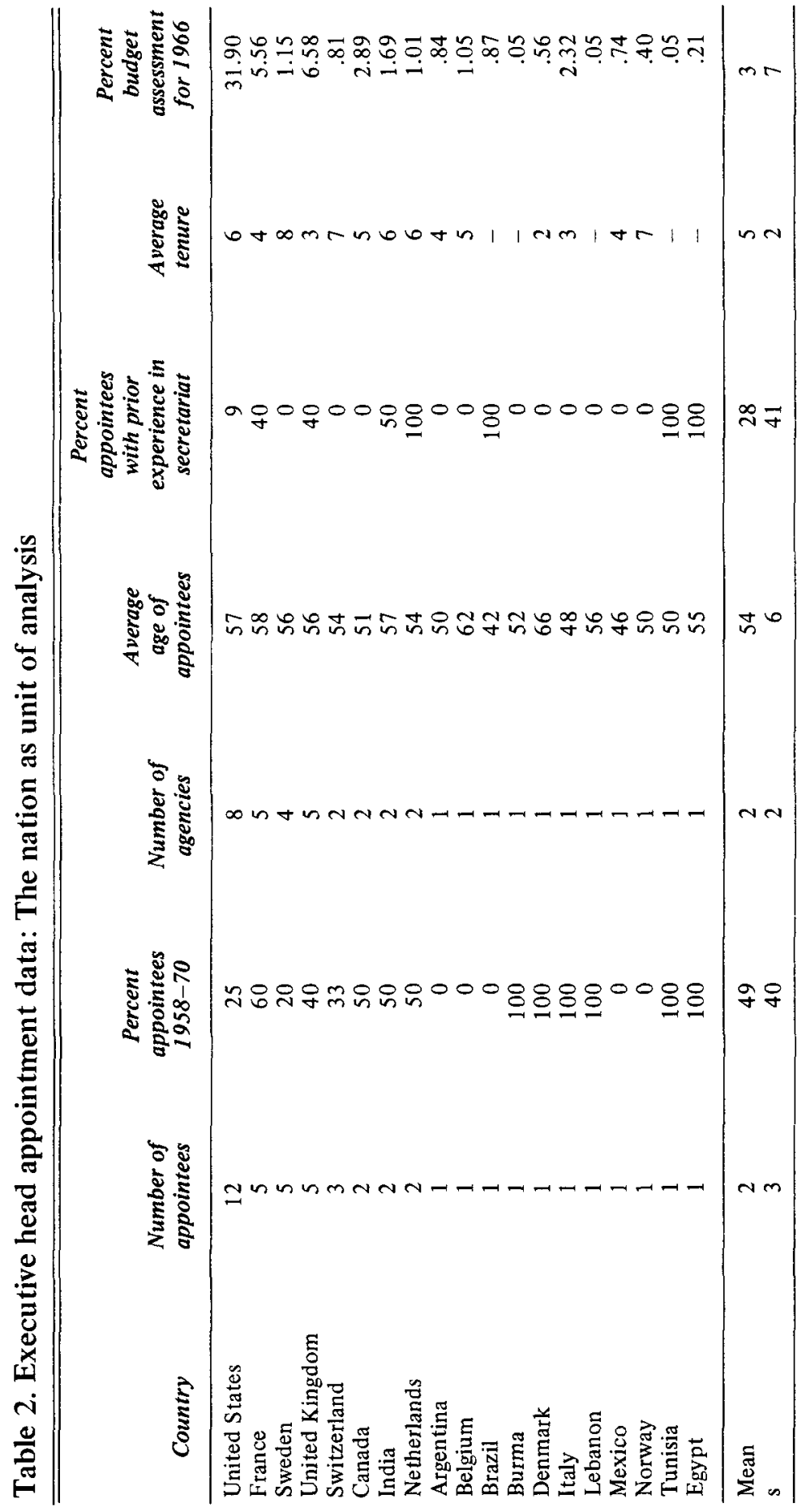


tions in the economic and social field which were known as specialized agencies. ${ }^{8}$ These specialized agencies plus the United Nations itself comprise the fifteen organizations reported upon in this article.

There is no such thing as a typical or normal organization in this group. In fact, considerable variation exists in agency practices and characteristics. In order to gain some perspective on the agencies, data were collected for 1966 on eleven selected organizational characteristics for each of the agencies. These data are summarized in table $3 .^{9}$ As can be seen from the size of the standard deviations the dispersion about the mean is relatively large in most instances. Furthermore, coefficients measuring kurtosis and skewness indicate that for most variables the deviation from a normal distribution is considerable. These findings are a reflection of diversity among the organizations on these particular variables.

\section{Table 3. Summary of organizational data}

\begin{tabular}{lrrrr}
\hline \multicolumn{1}{c}{$\begin{array}{c}\text { Organizational } \\
\text { characteristic }\end{array}$} & Mean & $\boldsymbol{s}$ & $\begin{array}{c}\text { Kurtosis } \\
\text { coefficient }\end{array}$ & $\begin{array}{c}\text { Skewness } \\
\text { coefficient }\end{array}$ \\
\hline Age of agency & 29 & 29 & 1.65 & 1.77 \\
$\begin{array}{l}\text { Number of members } \\
\text { Total secretariat }\end{array}$ & 110 & 19 & .39 & -1.05 \\
$\begin{array}{l}\text { Total expenditures } \\
\text { (\$000) }\end{array}$ & 1,911 & 2,716 & 4.19 & 2.16 \\
$\begin{array}{l}\text { Percent regular budget } \\
\text { Percent secretariat } \\
\text { on technical assistance }\end{array}$ & 6,052 & 45,556 & .49 & 1.27 \\
$\begin{array}{l}\text { Percent assessment } \\
\text { largest contributor }\end{array}$ & 17 & 24 & -1.38 & .29 \\
$\begin{array}{l}\text { Years between assembly } \\
\text { meetings }\end{array}$ & 25 & 16 & -1.79 & -.08 \\
$\begin{array}{l}\text { Percent members on } \\
\text { executive board }\end{array}$ & 2 & 10 & .31 & -1.31 \\
$\begin{array}{l}\text { Number regional offices } \\
\begin{array}{l}\text { NGOs with official } \\
\text { relations }\end{array}\end{array}$ & 21 & 2 & -.25 & 1.16 \\
\hline
\end{tabular}

\footnotetext{
${ }^{8}$ In a legal sense there were only thirteen specialized agencies in 1966. The International Atomic Energy Agency (IAEA) has been treated as a specialized agency because by most non-legal criteria it is considered to be one.

${ }^{9}$ The data which form the basis of table 3 were collected from various documents issued by UN agencies. This data set is available from the International Organization Data Archive of the International Studies Association, which is located at Indiana University. A copy of the data, intercoder reliability information and a listing of the data sources can be obtained by writing to the author of this article. The summary statistics reported in table 3 were calculated on the CDC 6600 Computer at Indiana University's Wrubel Computing Center. The SPSS program was used.
} 
In order to obtain a more parsimonious description of the dimensions along which these characteristics fall, a factor analysis was performed. The $\mathrm{R}$ factor analysis was carried out using the product moment correlation coefficient, a principal components solution, unities in the diagonal, a cutoff of an eigenvalue of 1.0 and Varimax rotation. ${ }^{10}$ The unrotated and rotated factor matrices are presented in table 4 . Three factors emerged which account for eighty-one percent of the total variance in the correlation matrix. By looking at the final communalities it can be seen that most of the variance in the variables is contained in the extracted factors.

The unrotated first factor accounts for thirty-nine percent of the total variance. As indicated by the factor loadings it is characterized by strong relationships with the following variables: number of members, total secretariat, total expenditures, percent regular budget, percent secretariat on technical assistance, percent members on executive board, number regional offices, and nongovernmental organizations (NGOs) with official relations. These variables are all characteristic of organizations with large staffs and programs of action, and this first dimension will be labeled the resources factor. The unrotated second factor accounts for thirty percent of the total variance in the correlation matrix. This factor is characterized by strong relationships with the following variables: Age of agency, number of members, percent assessment largest contributor, and years between assembly meetings. It appears to be measuring differences between agencies which follow a pattern for international organizations established before the Second World War and newer agencies which follow a pattern established after the founding of the United Nations. It will be labeled the age factor. The unrotated third factor accounts for twelve percent of the total variance and is characterized by a strong relationship with only one variable: Percent of secretariat on technical assistance. It will be labeled the technical assistance factor.

To clarify the interpretation of the factors an orthogonal rotation was performed. To get an indication of the relationship among the sample agencies the factor scores for the first two rotated factors have been plotted in diagram 1. As can be seen the United Nations (UN), Food and Agriculture Organization (FAO), World Health Organization (WHO), United Nations Educational, Scientific and Cultural Organization (UNESCO), and the World Bank (IBRD) all fall into the upper left hand quadrangle. The International Labor Organization (ILO) and International Monetary Fund (IMF) are located nearby. It is interesting to note

\footnotetext{
${ }^{10}$ The factor analysis was done on the CDC 6600 Computer at Indiana University's Wrubel Computing Center. The SPSS factor analysis program PA1 was used. Some noise may have been introduced into the analysis because of deviation from the normal distribution by certain of the arrays of data. I considered transforming the data, but, in the final analysis, decided not to do so. It is my feeling that the product moment correlation coefficient is robust and partially compensates for this problem. I chose to keep everything as simple as possible. A copy of the correlation matrix and other details regarding the factor analysis can be obtained by writing to the author of this article.
} 


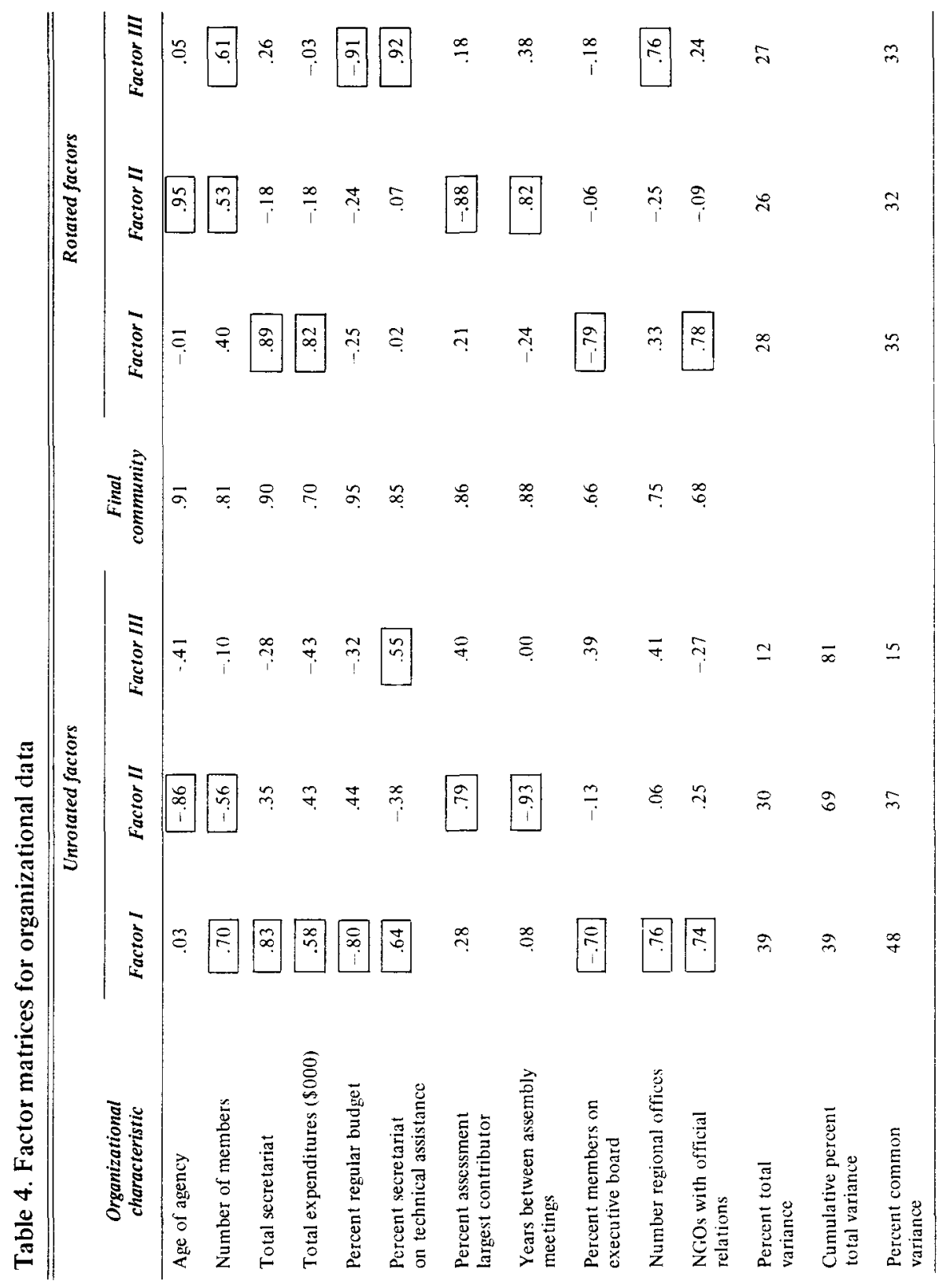




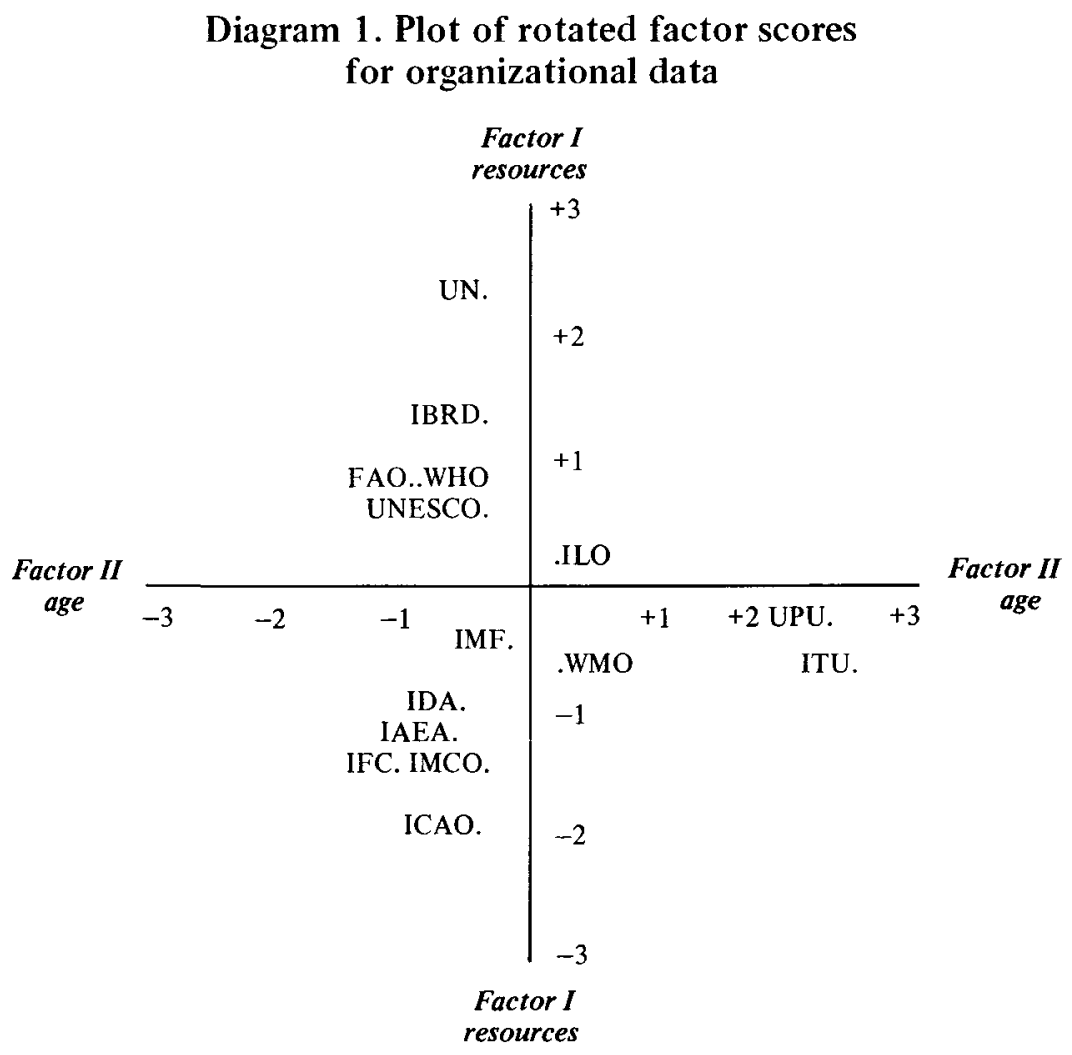

how the International Development Association (IDA), International Atomic Energy Agency (IAEA), International Finance Corporation (IFC), Intergovernmental Maritime Consultative Organization (IMCO), International Civil Aviation Organization (ICAO), and World Meteorological Organization (WMO) are clustered together. The Universal Postal Union (UPU) and International Telecommunication Union (ITU) are located near each other and at some distance from the other agencies.

There is a great deal of face validity to the scaling, and thus the perspective, produced by the factor analysis. The reason for the use of factor analysis was so that specific values would be systematically assigned to a reduced number of organizational characteristics, facilitating the inclusion of these organizational factors in further analysis. The rotated factor scores will be used as indicators of the characteristics of organizations in the empirical examination reported in this article. These scores are presented in table 5 along with a recoding of data from table 1 . 


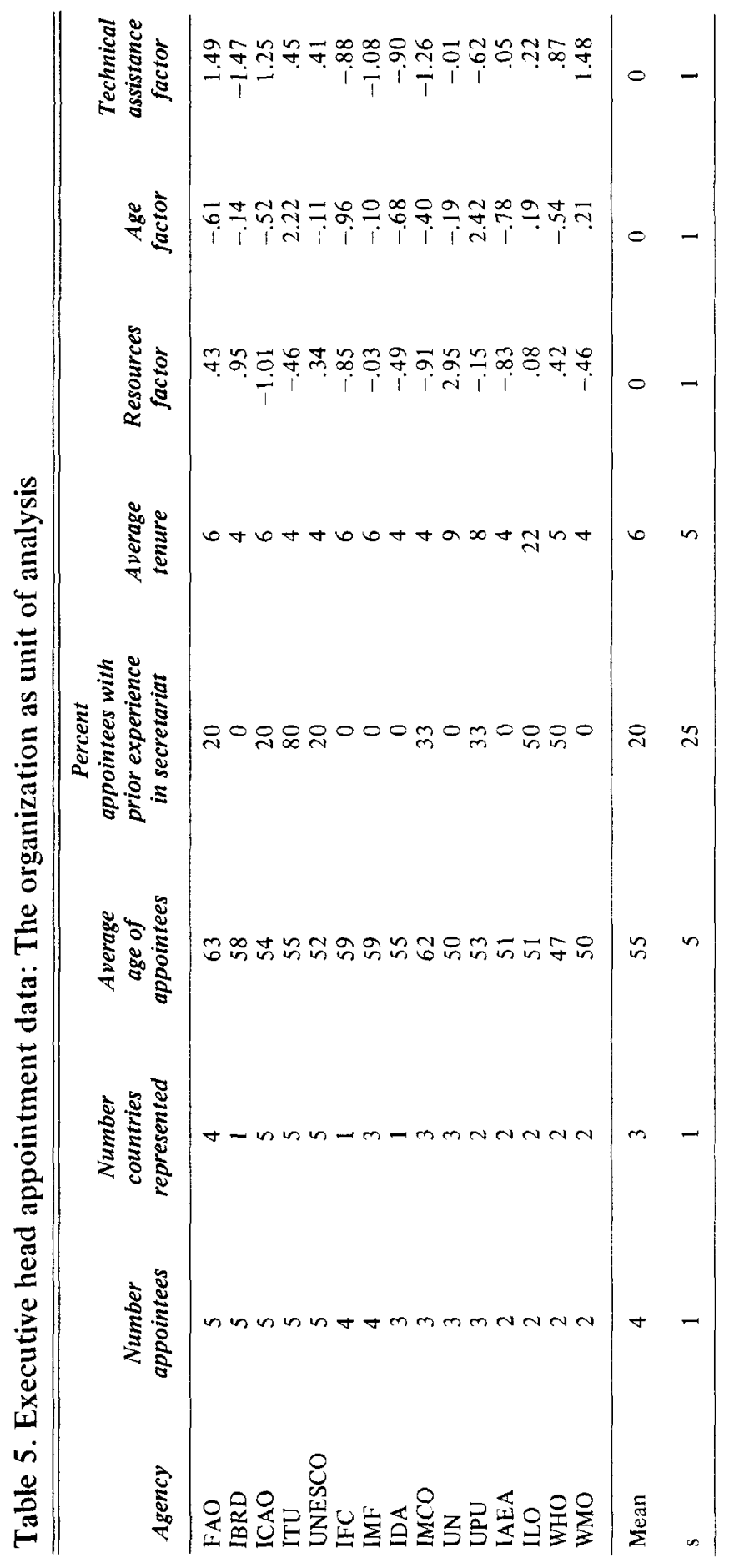


It is interesting to note in table 5 that the number of appointees per organization ranged from two to five, with an average of four for the twenty-six year period. The average number of countries varied from a low of one (for the World Bank Group) to five, with the average being three per agency. The average age of appointees ranged from a low of forty-seven to a high of sixty-three, with the average being fifty-five years. The overall organizational norm seemed to be to appoint individuals without prior experience as a member of the secretariat of the agency; eight of the fifteen organizations did not appoint anyone with prior experience and only the International Telecommunication Union (ITU) appeared to follow a practice of appointing secretariat members to the position of executive head. The average tenure (of those no longer in office in 1970) ranged from four to twenty-two years, with the average being six years per agency.

Thus for the purpose of the empirical examination reported in this article the agency scores for the dimensions resulting from the rotated factor scores were used to index organizational characteristics, national characteristics were indexed by the percentage of assessment for 1966 assigned to the appointee's native country, and personal characteristics were indexed by the individual's age upon assuming office and years of prior experience in the agency secretariat. ${ }^{11}$ The appointees were divided into those who first assumed office between 1945 and 1957 and those doing so between 1958 and 1970. There are, of course, problems associated with this particular set of operational procedures. For example, the indicators tap only part of the organizational, national, and personal characteristics in which there is potential interest and the division of appointees into groups is arbitrary. While the operationalization is far from perfect, it nevertheless seems to be adequate for the purpose of a preliminary examination of whether changes have taken place in the emphasis involved in the selection of executive heads in UN treaty-based organizations.

\section{Empirical examination of changes in emphasis in the executive head selection process}

For the purpose of the empirical analysis of changes in emphasis the executive head appointment function was specified to be of the following form: $Z=a+$ $b_{1} X_{1}+b_{2} X_{2}+b_{3} X_{3}+b_{4} X_{4}+b_{5} X_{5}+b_{6} X_{6}+e$, where $Z$ is appointment as executive head, $X_{1}$ is the resources factor score for the organization, $X_{2}$ is the age factor score for the organization, $X_{3}$ is the technical assistance factor score for the organization, $\mathrm{X}_{4}$ is the 1966 percent of assessment for the native country of the individual, $X_{5}$ is the age of the individual upon the assumption of office, $X_{6}$ is the amount of prior experience which the individual had in the secretariat, $\mathrm{b}_{1}$ through

${ }^{11}$ Three individuals were appointed to head the IBRD, IFC and IDA at the same time. For those appointees the IBRD data were used for the organizational indices. 
$b_{6}$ are parameters attached to the variables, $a$ is an intercept, and e is an error term to take into account circumstances not otherwise contained in the equation.

The data analytic technique used was discriminant function analysis. ${ }^{12}$ It began with the calculation of the means for the variables for the two groups. ${ }^{13}$ Those values are presented in table 6 . The differences in the average percent of assessment paid by the appointee's native country and the average prior experience in the agency's secretariat are the most striking. The Generalized Mahalanobis D Square for the entire data set was then calculated. Its value was 19.64 . It can be

Table 6. Mean scores for predictor variables

\begin{tabular}{lcc}
\hline \hline & $\begin{array}{c}1945-57 \\
\text { Group } \\
(\boldsymbol{n}=27)\end{array}$ & $\begin{array}{c}1958-70 \\
\text { Group } \\
(\boldsymbol{n}=20)\end{array}$ \\
\hline Resources factor score & .25 & -.06 \\
Age factor score & -.01 & .34 \\
$\begin{array}{l}\text { Technical assistance factor score } \\
\begin{array}{l}\text { assessment for native country } \\
\text { of appointee }\end{array}\end{array}$ & .35 & -.07 \\
$\begin{array}{l}\text { Age upon assuming office } \\
\text { Prior experience in secretariat }\end{array}$ & 12.32 & 6.87 \\
\hline
\end{tabular}

${ }^{12}$ For an introduction to discriminant function analysis see William W. Cooley and Paul R. Lohnes, Multivariate Data Analysis (New York: John Wiley and Sons, Inc., 1971): 243-86. The acceptance of the assumptions contained in discriminant function analysis is a refinement of the executive head appointment function. In future studies alternative ways of specifying the function should be considered.

${ }^{13}$ All data analysis in this section was done on the CDC 6600 Computer at Indiana University's Wrubel Computing Center. The BMD 5M Discriminant Analysis program was used. 
Table 7. Classification matrix for discriminant function analysis

\begin{tabular}{lccc}
\hline & \multicolumn{3}{c}{ Actual group } \\
\cline { 2 - 4 } Predicted group & $1945-57$ & $1958-70$ & Totals \\
\hline $1945-57$ & 20 & 6 & 26 \\
$1958-70$ & 7 & 14 & 21 \\
Totals & 27 & 20 & \\
& & & \\
& & Percent hits $=72$ & \\
\hline
\end{tabular}

interpreted as a $\mathrm{X}^{2}$ test which tells whether the difference between groups is statistically significant. If the assumptions of the statistic had been met a value this large would have been interpreted as indicating that the groups are significantly different at the .01 level.

The discriminant function analysis yielded the classification matrix reported in table $7 .{ }^{14}$ As can be seen the executive head appointment function adequately discriminated between the two groups of appointees, correctly classifying thirty-four of the forty-seven individuals (72 percent). The function predicted twenty-six appointments for the first period whereas twenty-seven appointments were made. It predicted twenty-one appointments for the second period whereas twenty were actually made. These results provide support for the contention that the emphasis

14 The following discriminant function coefficients were used:

\begin{tabular}{lcc}
\hline & Function 1 & Function 2 \\
\hline Resources factor score & 2.27 & 1.81 \\
Age factor score & 2.00 & 1.86 \\
Technical assistance factor score & 3.24 & 2.36 \\
1966 percent of budget assessment & .01 & -.03 \\
for native country of appointee & & 1.28 \\
Age upon assuming office & 1.34 & -.15 \\
Prior experience in secretariat & -.32 & -34.60 \\
Intercept & -38.04 & \\
\hline
\end{tabular}


in the selection process differed during the two halves of the period under examination. ${ }^{15}$

The details of the classification of the individuals in the sample are presented in table 8 along with the probability of each individual's classification into each group. It is fascinating to study the table, examining the probability each individual had of belonging to the group appointed during each of the time periods. It is of particular interest to analyze the appointments which were incorrectly classified because they may give a clue to the reason for the errors. Unfortunately there is no obvious set of new variables which emerge from a misclassification analysis and suggest themselves for inclusion in a revised executive head appointment function.

\section{Conclusion and suggestions for further research}

Because it was possible to distinguish, on the basis of the specified executive head appointment function, between executive heads appointed during the two

\begin{tabular}{|c|c|c|c|c|c|}
\hline Name & Country & $\begin{array}{l}\text { Organi- } \\
\text { zation }\end{array}$ & Term & $\begin{array}{c}\text { Age upon } \\
\text { assuming } \\
\text { office }\end{array}$ & $\begin{array}{l}\text { Prior expe- } \\
\text { rience in } \\
\text { secretariat }\end{array}$ \\
\hline Kurt Waldheim & Austria & UN & $1972-$ & 54 & 0 \\
\hline H. Johannes Witteveen & Netherlands & IMF & $1973-$ & 52 & 0 \\
\hline C. P. Srivastava & India & IMCO & 1973- & 53 & 0 \\
\hline Anthony H. Ridge & UK & UPU & $1973-$ & 60 & 9 \\
\hline Hafdan Mahler & Denmark & WHO & $1973-$ & 50 & 22 \\
\hline
\end{tabular}

The data on these individuals were collected from the following sources: Who's Who 1974 (London: Adam and Charles Black, 1974); The International Who's Who, Thirty-Sixth Edition, 1972-73 (London: Europa Publications Limited, 1972); The International Year Book and Statesmen's Who's Who 1974 (London: Mercury House Reference Books, 1974); and International Monetary Fund, Annual Report 1973 (Washington, D.C.: International Monetary Fund, 1973). These individuals were included in the second group of appointees (which became the 1958-73 group) and the discriminant function analysis program was run again. The coefficients in the functions changed slightly. The new analysis correctly classified thirty-seven out of fifty-two appointees ( 71 percent, compared with 72 percent for the prior analysis). The Mahalanobis D Square went up slightly to 24.12 (from 19.64). The inclusion of this new data does not seem to make much difference in the general results obtained. Secretary-General Waldheim was the only one of the new appointees who was misclassified. He had a .34 probability of belonging to the second group. The only individual who was reclassified was Eugene Black, who had a new probability of .503 of belonging to the second group. 
Table 8. Individual classifications

\begin{tabular}{|c|c|c|c|}
\hline Name & $\begin{array}{c}\text { Group I } \\
\text { probability }\end{array}$ & $\underset{\text { probability }}{\text { Group } 2}$ & $\begin{array}{c}\text { Group } \\
\text { classification }\end{array}$ \\
\hline \multicolumn{4}{|l|}{ Group $1(1945-57)$} \\
\hline John Boyd Orr & .91 & .09 & 1 \\
\hline Trygve Lie & .74 & .26 & 1 \\
\hline Julian Huxley & .74 & .26 & 1 \\
\hline Eugene Meyer & .79 & .21 & 1 \\
\hline Camile Gutt & .39 & .61 & 2 \\
\hline Albert Roper & .70 & .30 & 1 \\
\hline John J. McCloy & .94 & .06 & 1 \\
\hline David A. Morse & .64 & .36 & 1 \\
\hline Norris E. Dodd & .97 & .03 & 1 \\
\hline Jaime Torres Bodet & .49 & .51 & 2 \\
\hline Brock Chisholm & .70 & .30 & 1 \\
\hline Eugene R. Black & .51 & .49 & $\hat{1}$ \\
\hline Fritz Hess & .45 & .55 & 2 \\
\hline Leon Mulatier & .39 & .61 & 2 \\
\hline Ivar Rooth & .41 & .59 & 2 \\
\hline Gustav Swoboda & .80 & .20 & 1 \\
\hline E.C.R. Ljungberg & .65 & .35 & 1 \\
\hline Dag Hammarskjold & .72 & .28 & 1 \\
\hline Luther H. Evans & .81 & .19 & 1 \\
\hline Marcolino Candau & .41 & .59 & 2 \\
\hline Philip V. Cardon & .96 & .04 & 1 \\
\hline Marco A. Andrada & .56 & .44 & 1 \\
\hline David A. Davies & .64 & .36 & 1 \\
\hline Binay R. Sen & .85 & .15 & 1 \\
\hline Per Jacobsson & .39 & .61 & 2 \\
\hline Robert L. Garner & .58 & .42 & 1 \\
\hline W. Sterling Cole & .65 & .35 & 1 \\
\hline \multicolumn{4}{|l|}{ Group $2(1958-70)$} \\
\hline Vittorino Veronese & .55 & .45 & 1 \\
\hline Gerald C. Gross & .38 & .62 & 2 \\
\hline R.M. Macdonnell & .70 & .30 & 1 \\
\hline Ove Nielsen & .30 & .70 & 2 \\
\hline U Thant & .76 & .24 & 1 \\
\hline Rene Maheu & .15 & .85 & 2 \\
\hline Edouard Weber & .37 & .63 & 2 \\
\hline Sigvard A. Eklund & .33 & .67 & 2 \\
\hline George D. Woods & .68 & .32 & 1 \\
\hline Pierre-Paul Schweitzer & .27 & .73 & 2 \\
\hline Jean Roullier & .33 & .67 & 2 \\
\hline Bernard T. Twigt & .33 & .67 & 2 \\
\hline Manohar B. Sarwate & .37 & .63 & 2 \\
\hline Michel Rahi & .04 & .96 & 2 \\
\hline Mohamed Mili & .28 & .72 & 2 \\
\hline Addeke H. Boerma & .14 & .86 & 2 \\
\hline Robert S. McNamara & .53 & .47 & 1 \\
\hline Colin Goad & .10 & .90 & 2 \\
\hline Wilfred Jenks & .00 & 1.00 & 2 \\
\hline Assad Kotaite & .66 & .34 & 1 \\
\hline
\end{tabular}


halves of the time period under study it is reasonable to conclude that the emphasis involved in the selection of executive heads, as specified by the function, has changed over time in UN treaty-based organizations. While this finding will not surprise careful observers of the UN system it, nevertheless, is the first time this has been systematically demonstrated.

Hopefully a more important contribution has been made by the provision of a basis for further research through the specification of the executive head appointment function and the identification and presentation of data which can be used in additional research. The recent volume by $\operatorname{Cox}$ and Jacobson has stimulated renewed interest in the study of policy making in international organizations. ${ }^{16}$ The work of Alker and associates in the peacekeeping issue-area ${ }^{17}$ and Hoole and associates in the budget field ${ }^{18}$ has demonstrated that it is possible to develop complex sets of fully specified policy-making rules which appear to correspond closely to actual activity in international organizations. If a behavioral theory of policy making in international organizations is to be developed then various issueareas must be studied. Because the appointment of individuals to serve as officers of organizations is among the important actions taken by an international organization, the study of policy-making rules in the appointment issue-area is important.

This research should be expanded to other organizations (e.g. regional organizations), other aspects of the appointment process (e.g. consideration but nonappointment), other foci (e.g. deputies to the executive head, parliamentary officers), and other empirical indicators (e.g. organizational appointment procedures) should be examined. This study made only a modest beginning in the development of a set of behavioral policy-making rules regarding appointments in international organizations. Considerable work remains to be done on the theoretical, methodological, and data levels. I encourage other scholars to engage in this research and hope that the material presented in this article will be helpful in that task.

\footnotetext{
${ }^{16}$ Robert W. Cox and Harold K. Jacobson, The Anatomy of Influence: Decision-Making in International Organization (New Haven: Yale University Press, 1973).

${ }^{17}$ Hayward R. Alker, Jr., and Cheryl Christensen, "From Causal Modelling to Artificial Intelligence: The Evolution of A UN Peace Making Simulation," in J. LaPonce and P. Smoker, eds., Experimentation and Simulation in Political Science (Toronto: University of Toronto Press, 1972): 177-224; and Hayward R. Alker, Jr., and William J. Greenberg, "The UN Charter: Alternative Pasts and Alternative Futures," in Edwin H. Fedder, ed., The United Nations: Problems and Prospects (St. Louis: Center for International Studies, University of Missouri, 1971): 113-42.

${ }^{18}$ Francis W. Hoole, "The Simulation of Alternative Budgetary Futures for the World Health Organization," in Fedder, ed., The United Nations: Problems and Prospects: 143-64; Hoole, Politics and Budgeting in the World Health Organization; and Francis W. Hoole, Brian L. Job and Harvey J. Tucker, "Incremental Budgeting and International Organizations," The American Journal of Political Science, forthcoming.
} 